\title{
Det första decenniet med tidskriften Högre utbildning
}

\author{
Cecilia Olsson Jers ${ }^{1 *} \&$ Åsa Lindberg-Sand ${ }^{2}$ \\ ${ }^{\mathrm{L}}$ Linnéuniversitetet, Sverige \& ${ }^{2}$ Lunds universitet, Sverige
}

Mitt i sommaren det märkliga pandemi-året 202I firade Högre utbildning sitt tioårsjubileum. Vi firade på distans genom att utlysa ett särskilt tema om vad Covid-I9-pandemin med övergång till distansutbildning och arbetet hemifrån inneburit för högre utbildning. Vi fick in mer än tjugo bidrag. Det första av dessa ingår i det här numret och presenteras nedan. Under 2022 kommer flera artiklar på temat.

Som en del av vårt tioårsjubileum har redaktionen också tillsammans gått igenom tidskriftens utveckling, sammanfattat den och klassificerat bidragen. Det är roligt att kunna konstatera att flödet av inskickade bidrag har ökat. Från 2018 till 202I har det nästan fördubblats. Samtidigt har självklart antalet publicerade bidrag också ökat, men inte alls i samma takt. Orsaken kan bland annat hittas i att det har blivit svårare att bli publicerad i Högre utbildning eftersom konkurrensen mellan bidragen har skärpts. Det i sin tur innebär att kvaliteten på de publicerade texterna har stigit. Denna positiva utveckling får dock konsekvenser för redaktionen eftersom både att läsa och bedöma manuskript samt att rekrytera lämpliga granskare, på olika sätt har blivit mer krävande. Därför behöver vi i redaktionen också bli flera. Under 2022 kommer vi att gå ut med en inbjudan att anmäla intresse för att ingå i vår redaktion, för ett nytt spännande decennium!

Men vad har det blivit av den tidskrift som sjösattes på konferensen NU2oıo? Initiativet kom från pedagogiska utvecklare inom Swednet och tidskriften fick även konkret stöd från högskolepedagogiska enheter vid en rad olika universitet. Särskild betydelse har stödet från enheterna inom U6 (universiteten i Göteborg, Linköping, Lund, Stockholm, Umeå och Uppsala) haft.

Under det första decenniet har sammanlagt 262 författare fått bidrag publicerade. Vilka lärosäten de kommer från visar både på tidskriftens ursprung och utveckling. Över femtio av författarna kommer från Lunds eller Uppsala universitet. Därutöver bidrar sju lärosäten med fler än fem författare vardera: Göteborg, Södertörn, Linköping, Stockholm, Malmö, Umeå och Örebro. Upp till fem författare kommer från vart och ett av ytterligare tretton svenska lärosäten. Tio författare kommer från universitet i de nordiska länderna samt fem från utomnordiska universitet i England, USA, Kanada och Japan. Vi har också gått ifrån en mångfald av bidragsformer och efterfrågar numera fyra: Artiklar, Reflekterad utbildningspraktik, Fördjupad diskussion och Recensioner.

Avsikten med tidskriften vid starten 2010 var att skapa en arena för svenskspråkig vetenskaplig och professionell kunskapsbildning kring högre utbildning och det akademiska lärarskapet. Förväntan om att undervisning i högre utbildning ska kunna utgå från ett forskningsbaserat kunnande gäller ju inte bara innehållet i själva ämnet utan också de didaktiska och pedagogiska förhållanden som formar undervisningen i det sociala sammanhanget. Och trots att det finns ett växande utbud av internationella forskningsresultat är det inte bara att läsa på och tillämpa. Undervisning i svensk högre utbildning kan nämligen ha sina särskilda förutsättningar vilket

*Författarkontakt: Cecilia Olsson Jers, e-post: cecilia.olsson_jers@lnu.se

Artiklar och reflektioner är kollegialt granskade. Övriga bidragstyper granskas av redaktionen. Se https://hogreutbildning.se ISSN 2000-7558

(C)2021 Cecilia Olsson Jers \& Åsa Lindberg-Sand. This is an Open Access article distributed under the terms of the Creative Commons Attribution 4.0 International License (https://creativecommons.org/licenses/BY/4.0/), allowing third parties to share their work (copy, distribute, transmit) and to adapt it, under the condition that the authors are given credit, that the work is not used for commercial purposes, and that in the event of reuse or distribution, the terms of this license are made clear.

Citation: Jers, C. O. \& Lindberg-Sand, A. (2021). "Det första decenniet med tidskriften Högre utbildning», Högre utbildning, 11(3), 119-121. https://doi.org/10.23865/hu.v11.3814 
kan göra det svårt att se hur internationella forskningsresultat kan tillämpas i svensk kontext. Och detta gäller även för mer övergripande frågor om hur högre utbildning utvecklas. Då blir forskning på nationell basis extra angelägen och tidskriften Högre utbildning är en inspirationskälla att tillgå både vad gäller forskning och praktik.

Det sista numret för 202I innehåller sju bidrag. De visar spännvidden i de frågor som engagerar författare i Högre utbildning.

\section{FÖRDJUPAD DISKUSSION}

I de flesta kurser har lärare i detalj planerat vilket innehåll studenterna ska arbeta med. I bidraget "Student-led education for a better world" reflections in conversation ifrågasätter Sachiko Ishihara, Aster Tommasini, Charlotte Ponzelar och Ewa Livmar självklarheten i en sådan utgångspunkt. I dialogform redogör de för sina erfarenheter som deltagare och ansvariga för i en kurs Reimagining education, i vilken studenterna var med och utformade innehållet. Deras kollaborativa resonemang visar att det finns goda skäl att överväga en annan sorts samverkan och ansvarsfördelning mellan studenter och lärare om man önskar att studenter ska skaffa sig kvalificerade förutsättningar att ta sig an svåra samhällsproblem.

\section{ARTIKLAR}

Anna-Lena Gohde och Ann-Marie Edström har undersökt hur kursplaner inom svenskämnet ramar in multimodalitet, som en aspekt av det studenterna förväntas lära under grundlärarprogrammet. Idag använder ungdomar appar och sociala medier där de hanterar både skriftspråk, bilder och filmer i sin kommunikation med varandra. Därigenom blir multimodalitet även en angelägenhet för lärarutbildningen. I kursplanerna framträder multimodalitet på tre sätt: som digitalitet, som stöd för annat lärande och som kunskapande i sin egen rätt. Det är främst när multimodalitet framträder på det sistnämnda sättet som processen kommer i fokus som en möjlig aktivitet för studenterna.

American Studies är en vanlig disciplin vid universitet i Nordamerika och i vissa europeiska länder, men den har inte fătt fäste i Sverige. Adam Hjorthén argumenterar i artikeln Curriculum development in American Studies: interdisciplinarity, student progression, and the Swedish-American paradox för att det ska bli så genom att diskutera den disciplinära historien och hur tvärvetenskap fokuseras i den amerikanska utbildningstraditionen. Hjortén ställer American Studies mot befintliga magisterstudier i Sverige för att tydliggöra utmaningen - men också möjligheten som finns för svenska studenter.

I Skrivehandlinger og andra handlinger: design av skriveoppgaver i lererutdanninga finns lärarstudenters skrivande i fokus. Ingunn Ofte och Hildegunn Otnes konstatera att när studenter skriver i akademin första gången är det angeläget med en genomtänkt design av skrivuppgiften. De båda har i en kvalitativ studie granskat ig ämnesdidaktiska uppgifter för att besvara frågan om hur uppgifterna är designade. Utifrån sin analys konstaterar Ofte och Otnes att uppgifterna är riktade mot det kommande läraryrket. Avslutningsvis diskuterar de de verb som används $\mathrm{i}$ skrivuppgifter och ägnar extra uppmärksamhet åt verbet "reflektera" och ställer sig frågan om det finns ett samförstånd hos lärarna som formulerar uppgifterna i vad "reflektera" innebär.

Det är angeläget att ta sig tid och reflektera över att vara handledare i PBL (problembaserat lärande) för att inte stagnera i sin roll. Det menar Elaine Sjögren och Anita Kärner Köhler efter att ha följt lärare som varit varandras kritiska vänner i grupphandledning. I artikeln The critical friend - a way to develop as a tutor in problem-based learning groups pekar de på att det är givande att följa grupphandledning från andra discipliner än den man själv tillhör. Genom 
att göra det stärks den egna disciplinära identiteten. Det var dessutom framgångsrikt att både vara en kritisk vän och att ha en kritisk vän eftersom reflektioner om att vara handledare då fördjupades.

Ett generellt problem för undervisande lärare är det som kallas för överföring och eller "transfer of learning", det vill säga förmågan att kunna överföra kunskaper mellan olika kontexter. I artikeln Kunskapsöverföring i det självständiga arbetet har Maria Wendt analyserat ett stort material bestående av intervjuer och deltagande observation utifrån att studenter står inför att skriva sin kandidatuppsats. Resultatet av studien visar att studenterna har överföringsproblem med form, innehåll och begrepp. De något nedslående resultaten diskuterar Wendt med hjälp av internationell forskning där tyngdpunkter oftast ligger på hur aktiva lärandesituationer skapas för att stödja studenterna i att ta vara på tidigare inhämtad kunskap.

När Covid-ı9 pandemin medförde att lärosäten gick över till distansundervisning påverkades både lärare och studenter. Annika Fjelkner, Torgny Roxå och Per Warfvinge skickade en enkät till studenter vid två olika lärosäten för att ta reda på hur deras nätverk förändrades av övergången. Av bidraget "It has worked well despite the circumstances" - a study on student social relations and well-being during the pandemic framgår att studenternas nätverk krympte från periferin, så att de främst kom att innefatta de studenter de redan innan hade många kontakter med. För de vars nära nätverk också krympte påverkades även välbefinnandet negativt.

\section{REFLEKTERAD UTBILDNINGSPRAKTIK}

Att använda videoessän som ett alternativt till mer traditionella examinationsformer lyfter Emil Stjernholm i en text med rubriken Videoessäer som pedagogisk metod för att utveckla medieoch informationskunnighet. Examinationsformatet möter både positiva och negativa reaktioner från studenterna. Några tycker att det utmanar och utvecklar deras förmåga att argumentera $\mathrm{i}$ rörlig bild. Andra tyckte att ovanan att uttrycka sig på detta visa hindrade dem och de efterlyste mer stöd till de praktiska momenten.

Johanna Lönngren har i flera år arbetat med att ta fram och använda wicked problems som en utgångspunkt för hur undervisning kan läggas upp. Det är en pedagogisk ansats som passar för komplexa problemområden som behöver förstås från flera olika infallsvinklar. Ett sådant område är till exempel hållbar utveckling. I Wicked problems i lärande för hållbar utveckling - Vägledning for att ta fram exempel och problembeskrivningar redovisas åtta forskningsbaserade designprinciper och flera konkreta exempel som stöd för lärare som vill bygga upp sin undervisning med denna ansats. 